\title{
Variances in airflows during different ventilation modes in a dynamic $U$-shaped cave
}

\author{
Jiří Faimon* and Marek Lang \\ Department of Geological Sciences, Faculty of Sciences, Masaryk University, Kotlářská 2, 61137 Brno, Czech Republic
}

\begin{abstract}
Airflow dynamics were studied in Císařská Cave (Moravian Karst, Czech Republic) under different seasonal conditions. The dependence of airflows on the difference between external and cave temperatures is nonlinear and roughly obeys the Darcy-Weisbach equation. The upward airflows were found to be systematically higher than the downward airflows under comparable driving forces. The principle reason is nonlinearity between air temperature and air density. U-shaped cave geometry magnifies this effect by feedback between external temperature and airflow driving forces. Whereas this feedback is positive during the upward airflow ventilation mode, it is negative during the downward airflow mode. To discuss the behavior in detail, a simplified model based on balancing the masses of two equivalent air columns of different temperatures and densities is proposed. The results contribute to a better understanding of cave microclimate evolution, cave $\mathrm{CO}_{2}$ dynamics, and speleothem growth.
\end{abstract}

Keywords: airflow; air density; cave; temperature difference; temperature profile; ventilation mode; conceptual model

Received 28 February 2012; Revised 13 December 2012; Accepted 12 February 2013

Citation: $\quad$ Faimon J. and Lang M., 2013. Variances in airflows during different ventilation modes in a dynamic U-shaped cave. International Journal of Speleology, 42 (2), 115-122. Tampa, FL (USA) ISSN 0392-6672 http://dx.doi.org/10.5038/1827-806X.42.2.3

\section{INTRODUCTION}

Cave air circulation is an important phenomenon that controls (1) cave microclimatology (Wigley \& Brown, 1971; de Freitas \& Littlejohn, 1987) and (2) speleothem growth via the impact of cave $\mathrm{PCO}_{2}$ (Banner et al., 2007; Baldini et al., 2008). In principle, cave airflows can be produced (1) dynamically, by moving fluids (Cigna, 1968), or (2) statically, by pressure differences derived from different air densities (Bögli, 1978; de Freitas et al., 1982). We have focused on the second mechanism because this one operates in the cave of interest. Generally, cave air circulation shows strong seasonality. Based on geometry, static caves with one entrance and dynamic caves with two and more entrances at different levels can be distinguished (Geiger, 1966). In contrast to static caves, dynamic caves ventilate throughout the entire year. In principle, cave airflows are controlled by external temperatures. If $\mathrm{T}_{\text {exterior }}<\mathrm{T}_{\text {cave }}$, upward airflows occur in the cave (external air enters the cave at the lower entrance and flows out from the cave at the upper entrance). This regime is called upward airflow ventilation mode (UAF mode). If $\mathrm{T}_{\text {exterior }}>\mathrm{Tc}_{\mathrm{ave}}$, cave airflows move the opposite way. In this case, we talk about downward airflow ventilation mode (DAF mode) (see Faimon et al., 2012 for detail).
A theoretical background on cave air circulation was given by Cigna (1968). Fundamentals of airflow impact on cave microclimate were developed by Wigley (1967) and Wigley \& Brown $(1971,1976)$. Previous works were focused on (1) both direct and indirect airflow monitoring (e.g., de Freitas \& Littlejohn, 1982; Dueñas et al., 1999; Pflitsch \& Piasecki, 2003; FernándezCortés et al., 2009) and (2) impact of air circulation on (i) cave microclimate (Luetscher et al., 2008; Russell $\&$ MacLean, 2008), (ii) cave $\mathrm{CO}_{2}$ (Kowalczk \& Froelich, 2010), or (iii) speleothem growth (Boch et al., 2011). Some attempts appeared to derive a complete model of cave air circulation (Christoforou et al., 1996; Jernigan \& Swift, 2001). Recently, a complex study on the ventilation and microclimatology in the Císařská Cave was presented by Faimon et al. (2012).

It is well known that winter airflows exceed summer airflows in some cavities. This phenomenon was documented by many studies on (a) airflows (Faimon et al., 2012), (b) radon activity (Tanahara et al., 1997; Dueñas et al., 2005, 2011; Gregorič et al., 2011), (c) $\mathrm{CO}_{2}$ concentrations (Bourges et al., 2001; Spötl et al., 2005), and (d) both the components (Kowalczk \& Froelich, 2010; Perrier \& Richon, 2010). We discuss this phenomenon based on (1) new data sets from the Císařská Cave (Moravian Karst) and (2) a simplified conceptual model. We follow the approach of Cigna 
(1968) that consists of balancing two equivalent air columns and calculating the driving forces for airflows under different external conditions. The goal of this study is to contribute to the better understanding of airflow behavior in dynamic caves.

\section{METHODS}

\section{Site of study}

Císařská Cave is formed in the Devonian limestones of the Macocha Formation in the northern part of the Moravian Karst, Czech Republic (Absolon 1970; Faimon et al., 2006, 2012). The position and vertical profile of the cave is given in Fig. 1. Two entrances at the altitudes of $460.7 \mathrm{~m}$ (lower entrance) and 470.7 $\mathrm{m}$ (upper entrance) ensure dynamic behavior of air circulation. Both entrances are equipped with steel doors, in which there are windows of $20 \times 20 \mathrm{~cm}$ in size (total area of $0.04 \mathrm{~m}^{2}$ ). The length of the cave is about $250 \mathrm{~m}$. The total volume of the cave is estimated to $\sim 11,500 \mathrm{~m}^{3}$. The rock overburden ranges from 15 to $35 \mathrm{~m}$. The external annual air temperature is about $10^{\circ} \mathrm{C}$; total annual precipitation is about $\sim 650 \mathrm{~mm}$. Presently, the Children Sanatorium with Speleotherapy (Ostrov u Macochy) practices speleotherapy in the cave. About 50 visitors stay in the cave for $\sim 20$ hours weekly.

\section{Monitoring}

All data were collected during the six monitoring campaigns between November 2010 and October 2012 , in order to cover the range of the seasonal conditions. The monitoring ran during a 5-day period between individual speleotherapeutic courses. Airflow was logged with 10-second time steps at one point in the center of the window in the lower entrance cave door. The temperatures for $\Delta \mathrm{T}$ calculations were logged at (i) the surface, about $50 \mathrm{~m}$ before the lower entrance, and (ii) in the cave, approximately in the middle of the cave length.

For a mapping of the vertical temperature distribution, temperature was measured (a) along the whole cave and (b) at the outside between the lower and upper cave entrances. Simultaneously, barometric pressure was measured with temperature
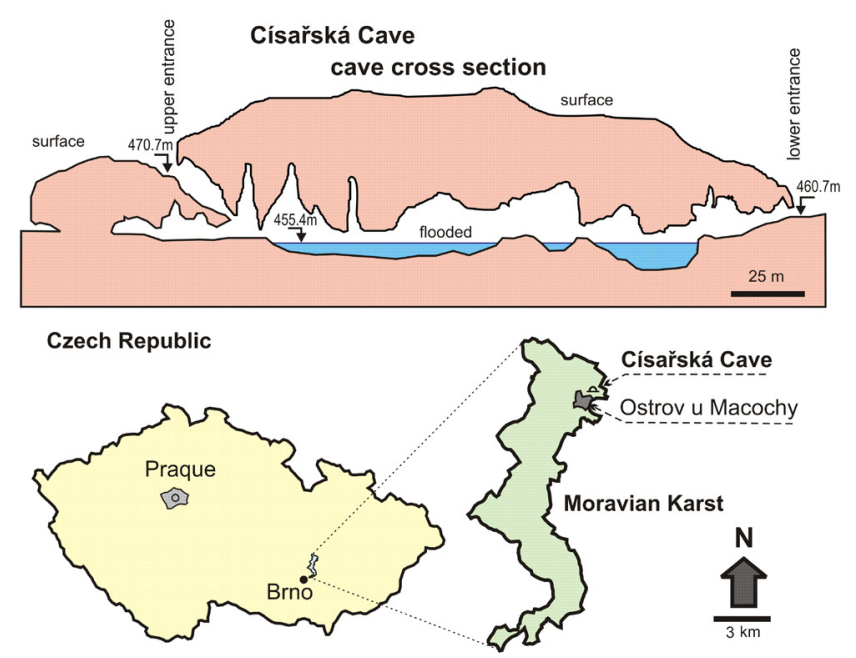

Fig. 1. The position and vertical profile of the Císařská Cave (based on Absolon, 1970). to estimate the altitude of the given site. Airflows were detected by the FVA935 TH4 thermo-anemometersensor (measuring range from 0.05 to $2 \mathrm{~m} \mathrm{~s}^{-1}$ with a precision of $\pm 0.04 \mathrm{~m} \mathrm{~s}^{-1}$ ) connected with the ALMENO 2290-4 V5 (Germany) Ahlborn datalogger. The linear velocity (in $\mathrm{m} \mathrm{s}^{-1}$ unit) was consecutively recalculated into volume velocity (in $\mathrm{m}^{3} \mathrm{~s}^{-1}$ ), based on the window cross-section area of $\sim 0.04 \mathrm{~m}^{2}$. The temperatures for the $\Delta \mathrm{T}$ calculation were measured by COMET S3120 dataloggers (measuring range from -30 to $+70^{\circ} \mathrm{C}$ with a precision of $\pm 0.4^{\circ} \mathrm{C}$ ). Vertical temperature distribution was measured by the Ahlborn $\mathrm{FH}$ A646-E1 thermo-sensor $\left(-20\right.$ to $0^{\circ} \mathrm{C}, \pm 0.4^{\circ} \mathrm{C}$; 0 to $70^{\circ} \mathrm{C}, \pm 0.1^{\circ} \mathrm{C}$ ). Barometric pressure was measured by the Ahlborn FDA612SA sensor (700 to 1050 mbar, \pm $0.5 \%)$. Both sensors were linked with the universal ALMENO 2290-4 V5 Ahlborn datalogger.

Statistical analysis was conducted using the Statistica 10, StatSoft Inc. program. (http://www.statsoft.com).

\section{RESULTS AND DATA ANALYSIS}

\section{Data}

The cave airflow data were gathered for external temperatures ranging between -8.1 and $30.5{ }^{\circ} \mathrm{C}$. Airflow is plotted against the temperature difference, $\Delta \mathrm{T}=\mathrm{T}_{\text {external }}-\mathrm{T}_{\text {cave }}$ (Fig. 2), assumed generally as the airflow driving force (e.g., Christoforou et al., 1996; Luetscher et al., 2008; Fernández-Cortés et al., 2009; Kowalczk \& Froelich, 2010; Boch et al., 2011). Note that the positive airflows correspond to the direction into the cave (inflowing air) and the negative ones to the direction from the cave (outflowing air) (Jernigan $\&$ Swift, 2001). Since the airflow data were gathered at the lower entrance, the positive values correspond to upward airflows (UAF ventilation mode) and the negative values correspond to downward airflows (DAF ventilation mode). At highly negative $\Delta \mathrm{T}$ (cold

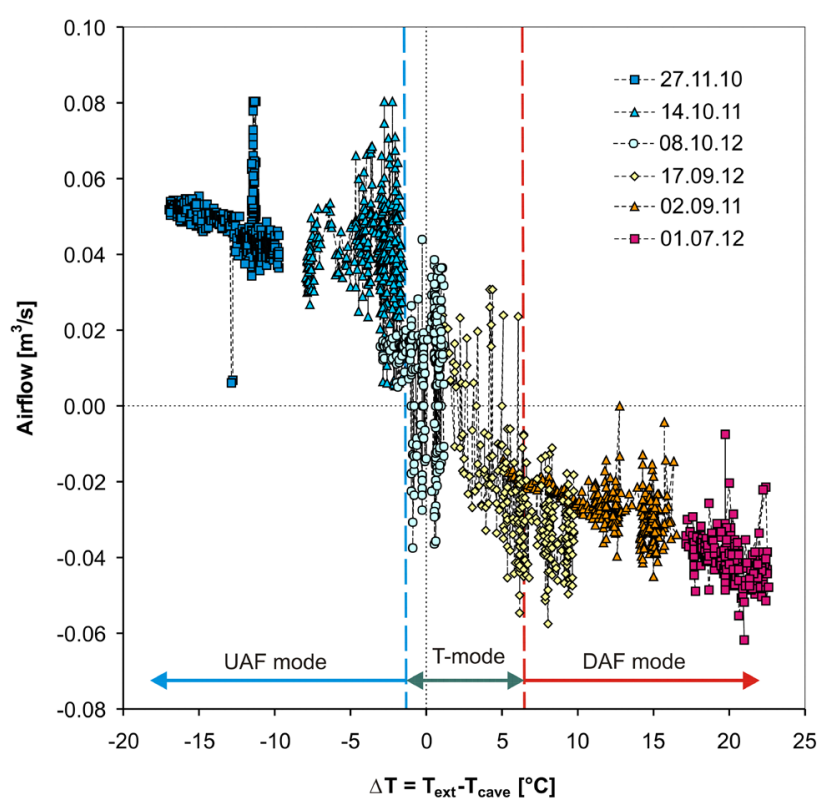

Fig. 2. The airflows measured at the lower entrance of Císařská Cave under different ventilation modes (UAF mode, T-mode, DAF mode; see text for details). The positive airflows enter the cave, the negative airflows exit of the cave. 
seasons), the airflows achieved mean values of about $0.055 \mathrm{~m}^{3} \mathrm{~s}^{-1}$. The peak values reached up to 0.08 $\mathrm{m}^{3} \mathrm{~s}^{-1}$. At the $\Delta \mathrm{T}$ between -2 and $7^{\circ} \mathrm{C}$, the airflows quickly changed their directions (transition mode). At $\Delta \mathrm{T}>7^{\circ} \mathrm{C}$, the airflows increased nonlinearly up to $-0.04 \mathrm{~m}^{3} \mathrm{~s}^{-1}$ (the peak values are $-0.06 \mathrm{~m}^{3} \mathrm{~s}^{-1}$ ). At all the modes, the airflows were unstable and oscillated with amplitudes up to $0.04 \mathrm{~m}^{3} \mathrm{~s}^{-1}$ and frequency from 0.3 to $40 \mathrm{mHz}$ (periods from 55 to 0.4 minutes) (Fig. 2). Enormous airflow instability and oscillations of highest amplitude are visible at transition mode at small driving forces $(\Delta \mathrm{T})$. At higher driving forces, airflows seem to be rather stabilized.

Data on the vertical distribution of temperature in both the exterior and the cave are reported in Table 1. They are listed relative to vertical levels: the lower entrance is at zero level, the upper entrance is at a level of $10 \mathrm{~m}$, and the cave's lowest point (CLP) is at a level of $-11 \mathrm{~m}$. Under different seasonal conditions, the mean cave temperatures ranged between 7.8 and $13.0{ }^{\circ} \mathrm{C}$ (see the columns \#1 to \#6 of Table 1 ). Moreover, cave temperature distribution varies according to airflow directions (ventilation modes). The highest temperature variations appear near the entrance, through which external air flows into cave. For purpose of a better analysis of airflow behavior, some "extreme artificial data" were proposed: (i) data with uniform temperatures through the individual external and cave environments (the columns \#78) and (ii) data with temperature gradients in the heterothermic zone associated with airflow input (the columns \#9-10 in Table 1).

\section{Regression analysis}

As known from fluid dynamics, the DarcyWeisbach equation relates the square of flow velocity to the head loss or pressure loss. Based on this equation, it was deduced that airflows should be a function of the square root of temperature difference, $\Delta \mathrm{T}$ (Luetscher \& Jeannin, 2004). Therefore, airflow data were regressed by the function,

$$
\mathrm{AF}=\mathrm{b} \sqrt{|\Delta \mathrm{T}|}
$$

where AF is volume airflow $\left(\mathrm{m}^{3} \mathrm{~s}^{-1}\right),|\Delta \mathrm{T}|=\mid \mathrm{T}_{\text {external }}{ }^{-}$ $\mathrm{T}_{\text {cave }}\left({ }^{\circ} \mathrm{C}\right)$, and $b$ is a constant representing slope of the dependence (for a physical meaning, see the Darcy-Weisbach equation). The values of $b$ vary between $1.39 \times 10^{-2}$ in the UAF mode and $-8.62 \times 10^{-3}$ in the DAF mode. Data fitted by the regression lines are in Fig. 3. Parameter estimates with the analysis of variance (ANOVA) are given in Table 2. As follows from the analysis, the dependence is rather weak (correlation coefficient $\mathrm{r}=0.60$ for UAF mode, and $\mathrm{r}$ $=0.74$ for DAF mode) but statistically significant $(\mathrm{p}<$ 0.001 at the level of confidence $\alpha=0.05$ ).

\section{Conceptual Model}

The model of the U-shaped cave consists of two equivalent air columns, (1) the inner column (IC) and (2) the combined column (CC) (Fig. 4a, b). The IC is situated in the cave between its upper entrance and its lowest point (CLP) given by the water table. The CC

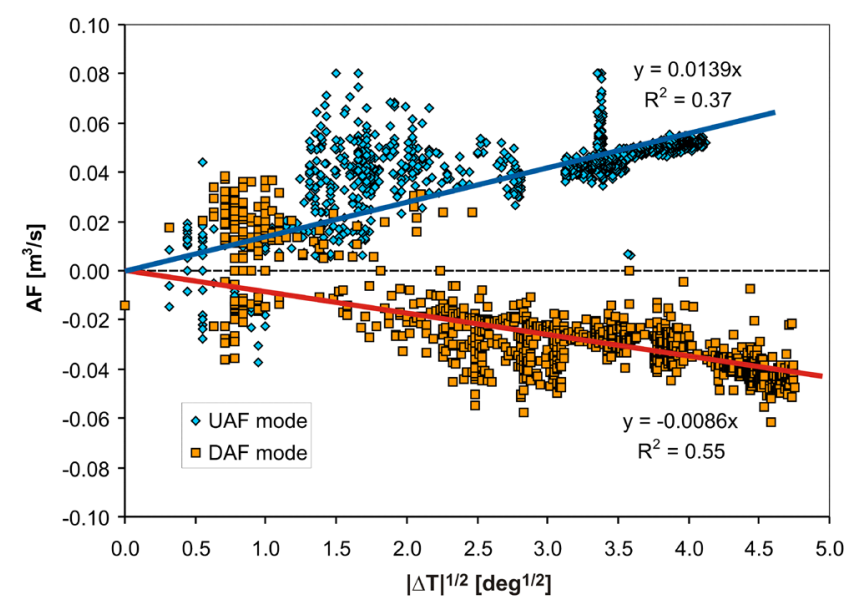

Fig. 3. Regression analysis of the airflows monitored under different ventilation modes.

\section{(b) equivalent air columns}

\section{(a) U-cave model}
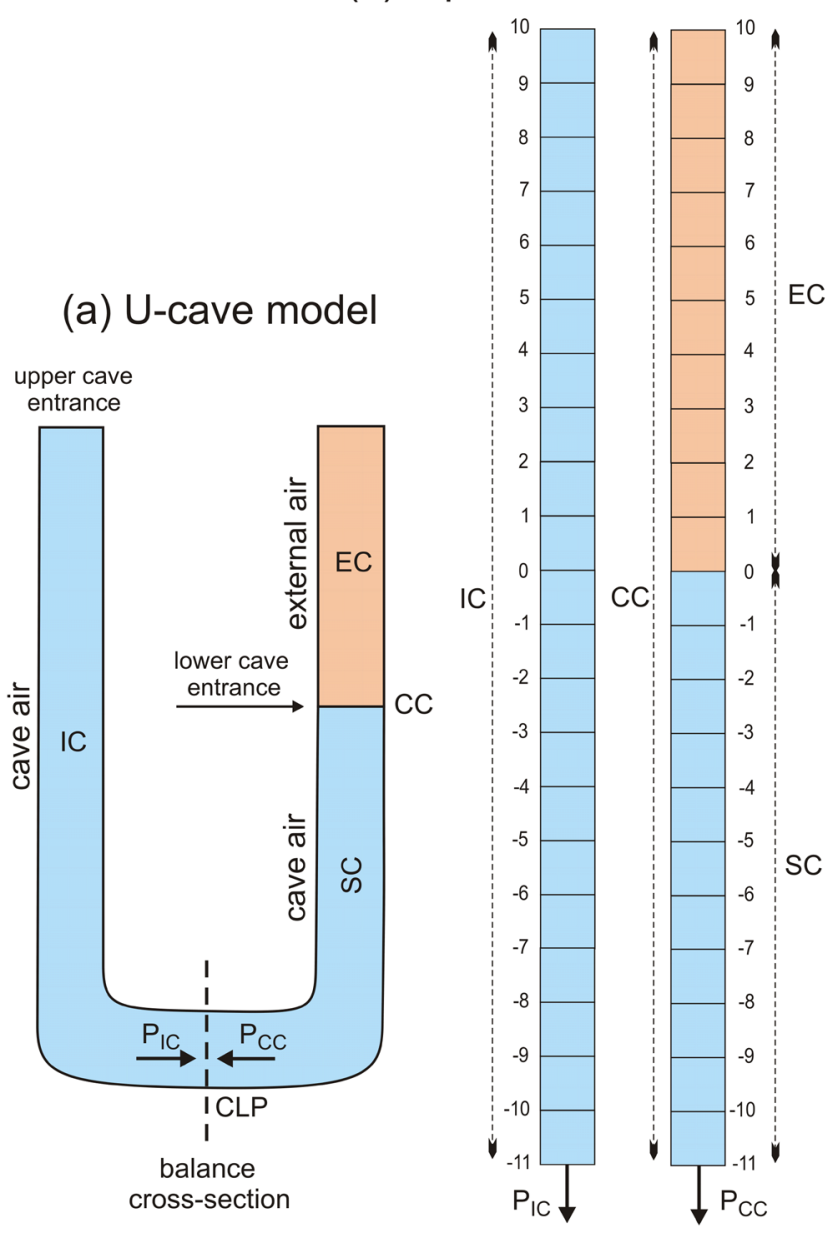

Fig. 4. Conceptual model of a U-shaped cave (a) and equivalent air columns (b). IC is the internal cave column. CC is the combined column consisting of the external air column (EC) and the short cave air column (SC). CLP is the cave lowest point. $\mathrm{P}_{\mathrm{IC}}$ and $\mathrm{P}_{\mathrm{CC}}$ are pressures derived from the individual column weights.

comprises of (1) the external air column (EC) located in the exterior between the upper and lower entrances, and (2) the short cave air column (SC) located in the cave between the lower entrance and CLP. Both the IC and $\mathrm{CC}$ are $21 \mathrm{~m}$ high, which is the vertical distance from the upper entrance level to the CLP. The crosssection area of the individual column is $1 \mathrm{~m}^{2}$. The airflow driving forces, i.e., pressure differences, result 
Table 1. Real and artificial data on the vertical distribution of cave/external temperatures.

\begin{tabular}{|c|c|c|c|c|c|c|c|c|c|c|c|c|c|}
\hline \multirow{2}{*}{\multicolumn{2}{|c|}{--- column --- }} & \multirow{3}{*}{$\frac{\text { site }}{\text { exterior UE }}$} & \multirow{3}{*}{$\begin{array}{l}\text { RVL } \\
\frac{\mathrm{h}[\mathrm{m}]}{9 \text { to } 10}\end{array}$} & \multicolumn{6}{|c|}{ real temperature data, $\mathrm{T}\left[{ }^{\circ} \mathrm{C}\right]$} & \multicolumn{3}{|c|}{ artificial temperature data, } & \multirow{3}{*}{$\begin{array}{l}{\left[{ }^{\circ} \mathrm{C}\right]} \\
10 \\
-10.0\end{array}$} \\
\hline & & & & \multirow{2}{*}{$\frac{1}{-3.2}$} & \multirow{2}{*}{$\frac{2}{0.2}$} & \multirow{2}{*}{$\frac{3}{10.1}$} & \multirow{2}{*}{$\frac{4}{17.9}$} & \multirow{2}{*}{$\frac{5}{20.7}$} & \multirow{2}{*}{$\frac{6}{29.8}$} & \multirow{2}{*}{$\frac{7}{30.0}$} & \multirow{2}{*}{$\frac{8}{-10.0}$} & \multirow{2}{*}{$\frac{9}{30.0}$} & \\
\hline $\mathrm{CC}$ & $\mathrm{EC}$ & & & & & & & & & & & & \\
\hline $\mathrm{CC}$ & $\mathrm{EC}$ & exterior & 8 to 9 & -3.6 & 0.1 & 10.0 & 17.9 & 20.6 & 29.5 & 30.0 & -10.0 & 30.0 & -10.0 \\
\hline $\mathrm{CC}$ & EC & exterior & 7 to 8 & -3.8 & 0.0 & 9.9 & 18.0 & 20.4 & 29.3 & 30.0 & -10.0 & 30.0 & -10.0 \\
\hline $\mathrm{CC}$ & $\mathrm{EC}$ & exterior & 6 to 7 & -4.0 & -0.2 & 9.8 & 18.0 & 20.3 & 29.2 & 30.0 & -10.0 & 30.0 & -10.0 \\
\hline $\mathrm{CC}$ & $\mathrm{EC}$ & exterior & 5 to 6 & -4.1 & -0.4 & 9.8 & 17.9 & 20.0 & 28.8 & 30.0 & -10.0 & 30.0 & -10.0 \\
\hline $\mathrm{CC}$ & EC & exterior & 4 to 5 & -4.2 & -0.5 & 9.7 & 17.9 & 19.9 & 28.5 & 30.0 & -10.0 & 30.0 & -10.0 \\
\hline $\mathrm{CC}$ & $\mathrm{EC}$ & exterior & 3 to 4 & -4.5 & -0.7 & 9.5 & 17.6 & 19.8 & 28.4 & 30.0 & -10.0 & 30.0 & -10.0 \\
\hline $\mathrm{CC}$ & EC & exterior & 2 to 3 & -4.5 & -1.0 & 9.5 & 17.4 & 19.4 & 28.0 & 30.0 & -10.0 & 30.0 & -10.0 \\
\hline $\mathrm{CC}$ & EC & exterior & 1 to 2 & -4.6 & -1.4 & 9.5 & 17.1 & 19.2 & 27.8 & 30.0 & -10.0 & 30.0 & -10.0 \\
\hline $\mathrm{CC}$ & EC & exterior LE & 0 to 1 & -4.6 & -1.9 & 9.4 & 16.8 & 19.1 & 27.4 & 30.0 & -10.0 & 30.0 & -10.0 \\
\hline $\mathrm{CC}$ & SC & cave LE & 0 to -1 & -1.8 & -0.4 & 9.6 & 14.2 & 11.4 & 19.9 & 10.0 & 10.0 & 10.0 & -1.8 \\
\hline $\mathrm{CC}$ & SC & cave & -1 to -2 & 0.6 & 1.2 & 9.7 & 14.0 & 9.5 & 15.4 & 10.0 & 10.0 & 10.0 & 0.6 \\
\hline $\mathrm{CC}$ & SC & cave & -2 to -3 & 2.6 & 2.9 & 9.7 & 13.9 & 9.2 & 13.1 & 10.0 & 10.0 & 10.0 & 2.6 \\
\hline $\mathrm{CC}$ & SC & cave & -3 to -4 & 4.2 & 4.8 & 9.4 & 13.9 & 9.1 & 12.3 & 10.0 & 10.0 & 10.0 & 4.2 \\
\hline $\mathrm{CC}$ & SC & cave & -4 to -5 & 5.4 & 6.8 & 9.3 & 13.8 & 9.0 & 12.3 & 10.0 & 10.0 & 10.0 & 5.4 \\
\hline $\mathrm{CC}$ & SC & cave & -5 to -6 & 6.3 & 7.1 & 9.1 & 13.9 & 8.8 & 12.4 & 10.0 & 10.0 & 10.0 & 6.3 \\
\hline $\mathrm{CC}$ & SC & cave & -6 to -7 & 6.9 & 7.2 & 9.1 & 13.9 & 8.7 & 11.9 & 10.0 & 10.0 & 10.0 & 6.9 \\
\hline $\mathrm{CC}$ & SC & cave & -7 to -8 & 7.3 & 7.2 & 9.0 & 13.5 & 8.5 & 11.7 & 10.0 & 10.0 & 10.0 & 7.3 \\
\hline $\mathrm{CC}$ & SC & cave & -8 to -9 & 7.4 & 7.3 & 8.8 & 12.6 & 8.2 & 11.4 & 10.0 & 10.0 & 10.0 & 7.6 \\
\hline $\mathrm{CC}$ & SC & cave & -9 to- 10 & 7.4 & 7.3 & 8.7 & 12.6 & 8.5 & 11.2 & 10.0 & 10.0 & 10.0 & 7.8 \\
\hline $\mathrm{CC}$ & SC & cave LP & -10 to -11 & 7.4 & 7.3 & 8.4 & 12.6 & 8.8 & 10.9 & 10.0 & 10.0 & 10.0 & 8.0 \\
\hline IC & & cave LP & -11 to -10 & 9.3 & 9.1 & 8.2 & 10.9 & 8.7 & 9.7 & 10.0 & 10.0 & 10 & 10.0 \\
\hline IC & & cave & -10 to -9 & 9.4 & 9.2 & 8.2 & 11.0 & 8.8 & 10.2 & 10.0 & 10.0 & 10.2 & 10.0 \\
\hline IC & & cave & -9 to -8 & 9.5 & 9.2 & 8.3 & 11.1 & 9.0 & 10.7 & 10.0 & 10.0 & 10.7 & 10.0 \\
\hline IC & & cave & -8 to -7 & 9.6 & 9.2 & 8.4 & 11.2 & 9.3 & 11.1 & 10.0 & 10.0 & 11.1 & 10.0 \\
\hline IC & & cave & -7 to -6 & 9.7 & 9.3 & 8.5 & 12.0 & 9.4 & 11.5 & 10.0 & 10.0 & 11.5 & 10.0 \\
\hline IC & & cave & -6 to -5 & 9.7 & 9.3 & 8.5 & 12.2 & 10.3 & 11.9 & 10.0 & 10.0 & 11.9 & 10.0 \\
\hline IC & & cave & -5 to -4 & 9.7 & 9.3 & 8.6 & 12.3 & 11.7 & 12.3 & 10.0 & 10.0 & 12.3 & 10.0 \\
\hline IC & & cave & -4 to -3 & 9.7 & 9.3 & 8.7 & 12.4 & 11.7 & 12.6 & 10.0 & 10.0 & 12.6 & 10.0 \\
\hline IC & & cave & -3 to -2 & 9.7 & 9.3 & 8.9 & 12.3 & 11.7 & 12.9 & 10.0 & 10.0 & 12.9 & 10.0 \\
\hline IC & & cave & -2 to -1 & 9.7 & 9.3 & 9.1 & 12.2 & 11.7 & 13.2 & 10.0 & 10.0 & 13.2 & 10.0 \\
\hline IC & & cave & -1 to 0 & 9.6 & 9.3 & 9.3 & 12.5 & 11.9 & 13.4 & 10.0 & 10.0 & 13.4 & 10.0 \\
\hline IC & & cave & 0 to 1 & 9.6 & 9.3 & 9.5 & 12.6 & 12.3 & 13.7 & 10.0 & 10.0 & 13.7 & 10.0 \\
\hline IC & & cave & 1 to 2 & 9.5 & 9.2 & 9.6 & 12.7 & 12.4 & 13.9 & 10.0 & 10.0 & 13.9 & 10.0 \\
\hline IC & & cave & 2 to 3 & 9.4 & 9.2 & 9.7 & 12.7 & 12.4 & 14.0 & 10.0 & 10.0 & 14.0 & 10.0 \\
\hline IC & & cave & 3 to 4 & 9.2 & 9.1 & 9.9 & 12.8 & 12.3 & 14.2 & 10.0 & 10.0 & 14.2 & 10.0 \\
\hline IC & & cave & 4 to 5 & 9.1 & 9.0 & 10.1 & 12.8 & 12.4 & 14.3 & 10.0 & 10.0 & 14.3 & 10.0 \\
\hline IC & & cave & 5 to 6 & 8.9 & 9.0 & 10.5 & 12.8 & 10.1 & 14.4 & 10.0 & 10.0 & 14.4 & 10.0 \\
\hline IC & & cave & 6 to 7 & 8.8 & 8.9 & 10.8 & 12.8 & 10.7 & 14.5 & 10.0 & 10.0 & 14.5 & 10.0 \\
\hline IC & & cave & 7 to 8 & 8.6 & 8.8 & 11.4 & 13.0 & 11.2 & 14.5 & 10.0 & 10.0 & 14.5 & 10.0 \\
\hline IC & & cave & 8 to 9 & 8.3 & 8.7 & 12.2 & 13.4 & 11.9 & 14.5 & 10.0 & 10.0 & 14.5 & 10.0 \\
\hline IC & & cave UE & 9 to 10 & 8.0 & 8.5 & 13.5 & 13.6 & 12.6 & 14.6 & 10.0 & 10.0 & 14.6 & 10.0 \\
\hline & & mean cave, $\mathrm{T}\left[{ }^{\circ} \mathrm{C}\right]$ & & 7.8 & 7.8 & 9.5 & 12.8 & 10.4 & 12.9 & 10.0 & 10.0 & 11.9 & 8.3 \\
\hline & & $\Delta \mathrm{T}\left[{ }^{\circ} \mathrm{C}\right]$ & & 11.9 & 8.4 & -0.3 & -4.9 & -9.6 & -15.7 & -20.0 & 20.0 & -18.1 & 18.3 \\
\hline & & $\Delta \mathrm{P}\left[\mathrm{N} / \mathrm{m}^{2}\right]$ & & 8.25 & 6.21 & 0.16 & -2.76 & -2.73 & -6.29 & -8.06 & 9.29 & -5.41 & 11.73 \\
\hline & & $|\Delta \mathrm{P}|\left[\mathrm{N} / \mathrm{m}^{2}\right]$ & & 8.25 & 6.21 & 0.16 & 2.76 & 2.73 & 6.29 & 8.06 & 9.29 & 5.41 & 11.73 \\
\hline & & ventilation mode & & UAF & UAF & UAF & DAF & DAF & DAF & DAF & UAF & DAF & UAF \\
\hline
\end{tabular}

RVL- relative vertical level; LP - lowest point; UE - upper entrance; LE - lower entrance, CC - combined column, EC- external column; SC - short cave column; UAF- upward airflow; DAF - downward airflow 
Table 2. Data regression analysis: the parameter estimates and analysis of variance (ANOVA).

\begin{tabular}{|c|c|c|c|c|c|}
\hline \multicolumn{6}{|c|}{ Parameter estimates } \\
\hline & b & SE & DF & $\mathrm{t}$-value & $\mathrm{p}$-value \\
\hline UAF mode & 0.0139 & 0.00012 & 1162 & 116.9 & 0.00 \\
\hline DAF mode & -0.0086 & 0.00013 & 955 & -65.6 & 0.00 \\
\hline \multicolumn{6}{|c|}{ ANOVA } \\
\hline UAF mode & ss & DF & MS & F-value & $\mathrm{p}$-value \\
\hline Regression & 2.15 & 1 & 2.1514 & 13659.9 & 0.00 \\
\hline Residual & 0.18 & 1162 & 0.0002 & & \\
\hline Total & 2.33 & 1163 & & & \\
\hline Corrected Total & 0.29 & 1162 & & & \\
\hline $\begin{array}{l}\text { Regression vs. Corrected } \\
\text { Total }\end{array}$ & 2.15 & 1 & 2.1514 & 8666.5 & 0.00 \\
\hline DAF mode & ss & DF & MS & F-value & $\mathrm{p}$-value \\
\hline Regression & 0.76 & 1 & 0.7590 & 4305.2 & 0.00 \\
\hline Residual & 0.17 & 955 & 0.0002 & & \\
\hline Total & 0.93 & 956 & & & \\
\hline Corrected Total & 0.37 & 955 & & & \\
\hline $\begin{array}{l}\text { Regression vs. Corrected } \\
\text { Total }\end{array}$ & 0.76 & 1 & 0.7590 & 1952.0 & 0.00 \\
\hline
\end{tabular}

SE- standard error, DF - degree of freedom, SS - Sum of Squares, MS - Mean Squares

from the differences in weights of the individual IC and CC. Note that the weights are balanced at the lowest point of the cave, not at the cave's lower entrance. To simplify pressure calculation, both the columns have been segmented into cells of $1 \mathrm{~m}^{3}$ volume, each one of unique temperature and density (Fig. 4b). The resulting pressure difference, $\Delta \mathrm{P}[\mathrm{Pa}]$, was calculated as

$$
\Delta \mathrm{P}=\mathrm{P}_{\mathrm{CC}}-\mathrm{P}_{\mathrm{IC}}
$$

where $\mathrm{P}_{\mathrm{CC}}$ and $\mathrm{P}_{\mathrm{IC}}$ are the pressures $[\mathrm{Pa}]$ derived from $\mathrm{CC}$ and IC weights $[\mathrm{kg}]$, respectively.

Air density is generally a function of temperature and concentrations of gasses, e.g., $\mathrm{CO}_{2}$ or/and water vapor. In this study, we only focused on temperature as the most important variable. Details on the impact of other variables on air density can be found in Kowalski \& Sánchez-Cañete (2010) or Sánchez-Cañete et al. (2013). Air density was calculated from the equation for ideal gas,

$$
\rho=\frac{P}{R_{\text {air }} T}
$$

where $\rho$ is air density $\left(\mathrm{kg} \mathrm{m}^{-3}\right), \mathrm{P}$ is barometric pressure $(\mathrm{P}=101,325 \mathrm{~Pa}), \mathrm{R}_{\text {air }}$ is the specific gas constant for air $\left(\mathrm{R}_{\text {air }}=287.058 \mathrm{~J} \mathrm{~kg}^{-1} \mathrm{~K}^{-1}\right)$, and $\mathrm{T}$ is temperature $(\mathrm{K})$.

The results of modeling based on real data (Table 1, column \#1 up to \#6) are consistent with actual ventilation modes observed. Data in columns \#1 up to \#3 confirmed predominance of $\mathrm{CC}$ mass (resulting in $\Delta \mathrm{P} \sim 8.25,6.21$, and $0.16 \mathrm{~Pa}$ ), which results in upward airflows (UAF mode). Data in columns \#4 up to \#6 show predominance of IC weight (resulting in $\Delta \mathrm{P} \sim-2.76,-2.73$, and $-6.29 \mathrm{~Pa}$ ) leading to downward airflows (DAF mode).
More advanced analysis of the "artificial" temperature data (Table 1, the column \#7 and 8) showed the mutually distinct pressure differences between IC and $\mathrm{CC}$ columns at different modes, $\Delta \mathrm{P}=$ -8.06 Pa (DAF mode) and 9.29 Pa (UAF mode), despite the same temperature difference, $|\Delta \mathrm{T}|=20^{\circ} \mathrm{C}$. The difference is achieved at uniform temperature distributions, separately in IC, SC, and EC. The pressure differences are invariant to SC length - the only crucial point is the difference between the levels of both cave entrances. If the cave air temperature near the entrances is affected by external air (see the "artificial" data in Table 1, column \#9 and 10), the pressure difference is magnified to $\Delta \mathrm{P}=-5.41$ $\mathrm{Pa}$ (DAF mode) and $11.73 \mathrm{~Pa}$ (UAF mode) despite the similar temperature differences, $\Delta \mathrm{T} \sim-18.1^{\circ} \mathrm{C}$ (DAF mode) and $18.3^{\circ} \mathrm{C}$ (UAF mode).

\section{DISCUSSION}

The peak airflow values up to $0.08 \mathrm{~m}^{3} \mathrm{~s}^{-1}$ found in the Císařská Cave are consistent with the values reported by Buecher (1999) for Kartchner Caverns (Arizona) or with those measured by Faimon et al. (2012) in the Císařská Cave earlier. Anyway, these values belong to very weak airflows in comparison with the fluxes of $2 \mathrm{~m}^{3} \mathrm{~s}^{-1}$ presented by Christoforou et al. (1996), 0.7-3.6 $\mathrm{m}^{3} \mathrm{~s}^{-1}$ given by Dueñas et al. (1999), or $3 \mathrm{~m}^{3} \mathrm{~s}^{-1}$ reported by Luetscher \& Jeannin (2004). Besides, these airflows are absolutely incomparable with the extreme airflows of $10-40 \mathrm{~m}^{3}$ $\mathrm{s}^{-1}$ (Corchia and Piaggia Bella, Italy) or even 100-200 $\mathrm{m}^{3} \mathrm{~s}^{-1}$ (Hwanseon Cave, Korea) mentioned by Badino (2010). The modeling of driving forces showed that the reason of such weak airflows is the small difference between the levels of both cave entrances. The frequencies of airflow oscillations from 0.3 to 40 $\mathrm{mHz}$ are roughly in the range reported by Plummer (1969). Further details on cave airflow oscillations can be found in Faust (1947), Cigna (1968), or Faimon et al. (2012).

The regression analysis confirmed the dependence of airflows on the square root of the temperature difference and, thus, the appropriateness of the Darcy-Weisbach equation. The found dependence is relatively weak $(r=0.60$, UAF mode; $r=0.74$, DAF mode). This is due to airflow instability and oscillations rather than temperature fluctuations. The difference in the $b$-parameter values, $|\mathrm{b}|=1.39 \times 10^{-2}$ for UAF mode and $|\mathrm{b}|=8.62 \times 10^{-3}$ for DAF mode, indicates inconsistency of airflow at distinct ventilation modes despite the same driving forces. The linear model AF $=\mathrm{f}(\Delta \mathrm{T})$ for the Císařská Cave lower entrance proposed by Faimon et al. (2012) gave the uniform slope dAF/ $\mathrm{d} \Delta \mathrm{T}=3.83 \times 10^{-3} \mathrm{~m}^{3} \mathrm{~s}^{-1} \mathrm{deg}^{-1}$ for both ventilation modes. The presented extensive data set allows one to specify the dependence more exactly, separately for both individual modes. For comparing both the previous and presented models, we may differentiate eqn. (1):

$$
\frac{\mathrm{dAF}}{\mathrm{d} \Delta \mathrm{T}}=\frac{\mathrm{b}}{2 \sqrt{\Delta \mathrm{T}}}
$$




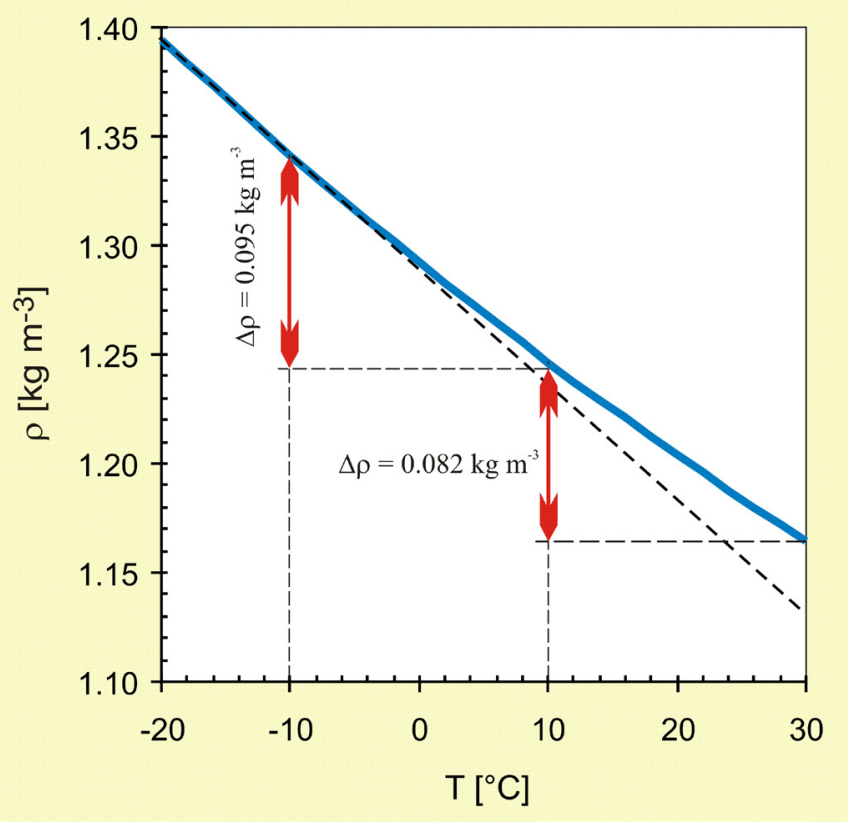

Fig. 5. Nonlinearity in the dependence of air density on temperature.

Inserting into equation (4) for the b-parameter and for $|\Delta \mathrm{T}|$ in the range from 1 to $15^{\circ} \mathrm{C}$ gives the gradient $\mathrm{dAF} / \mathrm{d} \Delta \mathrm{T}$ ranging from $1.39 \times 10^{-2}$ to $9.27 \mathrm{x}$ $10^{-4} \mathrm{~m}^{3} \mathrm{~s}^{-1} \mathrm{deg}^{-1}$ for the UAF mode and from $8.62 \mathrm{x}$ $10^{-3}$ to $5.75 \times 10^{-4} \mathrm{~m}^{3} \mathrm{~s}^{-1} \mathrm{deg}^{-1}$ for the DAF mode. As observed, the range of the values covers the value given by the previous model. The model shows that the airflows in different ventilation modes are inconsistent with each other despite the same $\Delta \mathrm{T}$. In other words, a U-shaped cave ventilates more intensively at the UAF mode (in cold seasons) in comparison with the DAF mode (in warm seasons). It is consistent with our empirical knowledge (de Freitas et al., 1982; Buecher, 1999; Dueñas et al., 1999; Spötl et al., 2005; Banner et al., 2007; Badino, 2010; Kowalczk \& Froelich, 2010).

Balancing of masses of IC and OC showed that pressures at the UAF mode exceeded the pressures at DAF mode at the same value of $\Delta \mathrm{T}$. In principle, this is due to nonlinearity of density dependence vs. temperature, as shown in Equation (3): the same shift in temperature causes a lesser shift in density at higher temperature (Fig. 5). For example, let couples of temperature in the cave and external air be (a) $\mathrm{T}_{\text {cave }}$ $=10{ }^{\circ} \mathrm{C}, \mathrm{T}_{\text {exterior }}=30{ }^{\circ} \mathrm{C}$ and (b) $\mathrm{T}_{\text {cave }}=10^{\circ} \mathrm{C}, \mathrm{T}_{\text {exterior }}=$ $-10{ }^{\circ} \mathrm{C}$. In spite of the same temperature difference $\left|\mathrm{T}_{\text {exterior }}-\mathrm{T}_{\text {cave }}\right|=20{ }^{\circ} \mathrm{C}$, the differences between air densities are distinct, $\Delta \rho=0.082 \mathrm{~kg} \mathrm{~m}^{-3}$ and $\Delta \rho=$ $0.095 \mathrm{~kg} \mathrm{~m}^{-3}$ in cases (a) and (b), respectively.

Actually, temperatures of the cave air near the entrances are influenced by external temperature, which lead to formation of a heterothermic zones (see, Wigley \& Brown, 1971; de Freitas \& Littlejohn, 1987; Luetscher et al., 2008). This effect predominates near the entrance, through which the external air enters a cave (see Table 1). The weaker effect at the opposite side of the cave (near the entrance, through which the air leaves the cave) was neglected at modeling for a better visualization. An impact of exiting cave air on EC weight was neglected as almost insignificant. Then, the airflow behavior is as follows.
During UAF mode, external cold air entering the cave by the lower entrance cools the air of SC and increases the weight of already heavier CC at this moment. This process creates positive feedback between external temperature and the driving force, which amplifies the differences between $\mathrm{CC}$ and IC weights. In this way, the airflow driving forces and, consecutively, cave airflows increase.

During DAF mode, a totally opposite effect operates at the upper entrance: warm and light external air penetrating the cave from the upper entrance lightens the heavier IC at this moment. It creates negative feedback between the external $\mathrm{T}$ and the driving forces, which decreases the weight differences between IC and $\mathrm{CC}$ and decreases cave airflows. Therefore, both processes participate in increasing the differences between the UAF and DAF airflows.

A tentative analysis of the airflow in caves of different geometries indicates substantive differences between behavior of a U-shaped cave and a straight-shaped cave. If temperatures were distributed uniformly through individual environments (cave air, external air), the geometry would not be important. Just the differences in the altitudes of lower and upper entrances would be crucial for airflow production in such a case. However, only temperature gradients in cave heterotrophic zones produce differences between behaviors of both cave types. Whereas feedback between external temperature and driving forces is positive during UAF-mode in a U-shaped cave, the same feedback would be negative in case of a straight cave. Because a straight cave does not comprise of any $\mathrm{SC}$, the cold external air directly enters the warmer and lighter IC at this moment and diminishes both the pressure differences and driving forces. Therefore, the positive feedback in U-shaped caves changes into the negative feedback in a straight cave during UAF mode. The feedbacks near the upper entrances remain negative regardless of cave geometry. Overall, such behavior results in lesser differences between the UAF and DAF modes in straight caves.

Despite the fact that annual cave temperature is believed to be near the annual external temperature (White, 1988), instantaneous mean cave temperatures can have a wide range. This is caused be the relatively short length of the cave with an insignificant or missing homothermic zone (Wigley \& Brown, 1971). Based on the annual external temperature $\sim 10{ }^{\circ} \mathrm{C}$, one would expect the ventilation modes to switch only at this temperature. However, data in Fig. 2 show a wide range of temperatures at which UAF and DAF switch over (T from 8 to 15 ${ }^{\circ} \mathrm{C}$ as follows from $\Delta \mathrm{T} \sim-2$ to $7{ }^{\circ} \mathrm{C}$ ). This is roughly consistent with cave mean temperatures varying in the range of 7.8 to $12.9{ }^{\circ} \mathrm{C}$ (Table 1). It indicates the importance of a "short-term history" of the temperature distribution in heterothermic zones for ventilation mode switching.

There is a consensus that cave air circulation controls cave microclimate (Wigley \& Brown, 1971, 1976; de Freitas \& Littlejohn, 1987; Buecher, 1999; Faimon et al., 2012) and, in such a way, also cave air $\mathrm{P}_{\mathrm{CO} 2}$ at least for part of the year (Bourges et al., 2001; 
Baldini et al., 2008; Kowalczk \& Froelich, 2010). The reduction of $\mathrm{P}_{\mathrm{CO} 2(\mathrm{~g})}$ supports dripwater degassing, an increase of water supersaturation with respect to calcite, and more intensive calcite precipitation, i.e., speleothem growth (Spötl et al., 2005; Banner et al., 2007). A distorted paleoenvironmental signal in speleothems may result from this process (McDermott, 2004; Fairchild et al., 2006; Boch et al., 2011). The changes in temperature/humidity of cave air can induce water condensation and corrosion of speleothems (Dublyansky \& Dublyansky, 1998; Dreybrodt et al., 2005). None of these phenomena are fully understood in all contexts. Based on this fact, cave air circulation will also require adequate attention in the future.

\section{CONCLUSIONS}

The airflows in the dynamic U-shaped Císařská Cave (Moravian Karst) were studied in dependence on (i) external/cave temperatures and (ii) cave ventilation modes. The study showed that cave airflows (1) depend on the square root of the temperature difference $\Delta \mathrm{T}=\mathrm{T}_{\text {external }}-\mathrm{T}_{\text {cave }}$ and (2) differ from each other during distinct ventilation modes.

The cave upward airflows (UAF ventilation mode, typical for cold seasons) generally exceed downward airflows (DAF ventilation mode, typical for warm seasons) under the same driving forces, $\Delta \mathrm{T}$. One reason is nonlinearity in the dependence of air density on temperature. Undoubtedly, this should be responsible for a predominance of upward airflows in all dynamic caves, regardless of their geometry. In the case of the U-shaped cave, airflows during UAF mode are amplified by positive feedback between external temperature and airflow driving forces. Cold external air entering the cave by the lower entrance increases the temperature gradient in the heterothermal zone, increases the mass of the already heavier cave air column, and increases the pressure difference between the inner and outer (combined) air columns. In contrast, such feedback is negative during DAF mode. In this case, the warm and light external air entering the cave from the upper entrance makes the heavy inner air column lighter, and, consecutively, reduces the pressure differences and driving forces.

Based on the modeled behavior, it can be deduced that only negative feedbacks appear in straight caves. They operate at both entrances and reduce the airflows during both ventilation modes. Therefore, the emphasized difference between upward and downward airflows is unique only in the case of U-shaped caves.

Furthermore, the study showed that the temperature of switching between individual ventilation modes varies with the "short-term temperature history" of a given cave. Based on an increasing understanding of the importance of cave circulation for karst processes, we believe that the results of this study may be of interest for microclimatologists, karsologists, speleologists, environmentalists, and paleoecologists.
ACKNOWLEDGEMENTS

The authors thank Dr. Marc Luetscher and two additional anonymous reviewers for valuable comments. Dr. Ondra Sracek is thanked for reading the manuscript. The work was supported by the MSM0021622412 grant of the Ministry of Education, Youth, and Sports and by the FR-TI1/482 grant of the Ministry of Industry and Trade of the Czech Republic.

\section{REFERENCES}

Absolon K., 1970 - Moravský kras (in Czech). Academia, Prague, $416 \mathrm{p}$.

Badino G., 2010 - Underground meteorology -"What's the weather underground?” Acta Carsologica, 39 (3): 427-448.

Baldini J.U.L., McDermott F., Hoffmann D.L., Richards D.A. \& Clipson N., 2008 - Very highfrequency and seasonal cave atmosphere PCO2 variability: Implications for stalagmite growth and oxygen isotope-based paleoclimate records. Earth and Planetary Science Letters, 272: 118-129. http://dx.doi.org/10.1016/j.eps1.2008.04.031

Banner J.L., Guilfoyle A., James E.W., Stern L.A. \& Musgrove M., 2007 - Seasonal variations in modern speleothem calcite growth in Central Texas, USA. Journal of Sedimentary Research, 77: 615-622. http://dx.doi.org/10.2110/jsr.2007.065

Boch R., Spötl C. \& Frisia S., 2011 - Origin and palaeoenvironmental significance of lamination in stalagmites from Katerloch Cave, Austria. Sedimentology, 58: 508-531. http://dx.doi.org/10.1111/ j.1365-3091.2010.01173.x

Bögli A., 1978 - Karsthydrographie und physische Speläologie. Springer, Berlin, 292 p.

Bourges F., Mangin A. \& d'Hulst D., 2001 - Carbon dioxide in karst cavity atmosphere dynamics: the example of the Aven d'Orgnac (Ardèche). Comptes Rendus de 1'Academie des Sciences Series IIA Earth and Planetary Science, 333: 685-692.

Buecher R.H., 1999 - Microclimate Study of Kartchner Caverns, Arizona. Journal of Cave and Karst Studies, 61: 108-120.

Christoforou C.S., Salmon L.G. \& Cass G.R., 1996 - Air exchange within the Buddhist cave temples at Yungang, China. Atmospheric Environment, 30: 3995-4006. http://dx.doi.org/10.1016/1352-2310(96)00123-9

Cigna A.A., 1968 - An analytical study of air circulation in caves. International Journal of Speleology, 3: 41-54. http://dx.doi.org/10.5038/1827-806X.3.1.3

deFreitas C.R.,LittlejohnR.N.,ClarksonT.S.\&KristamentS., 1982 - Cave climate: assessmentofairflowandventilation. International Journal of Climatology, 2: 383-397. http://dx.doi.org/10.1002/joc.3370020408

de Freitas C.R. \& Littlejohn R.N., 1987 - Cave climate: assessment of heat and moisture exchange. International Journal of Climatology, 7: 553-569. http://dx.doi.org/10.1002/joc.3370070604

Dreybrodt W., Gabrovšek F. \& Perne M., 2005 Condensation corrosion: A theoretical approach. Acta Carsologica, 34: 317-348.

Dublyansky V.N. \& Dublyansky Y.V., 1998 - The problem of condensation in karst studies. Journal of Cave and Karst Studies, 60: 3-17.

Dueñas C., Fernández M.C., Cañete S., Carretero J. \& Liger E., $1999-{ }^{222} \mathrm{Rn}$ concentrations, natural flow rate and the radiation exposure levels in the Nerja Cave. Atmospheric Environment, 33: 501-510. http://dx.doi.org/10.1016/S1352-2310(98)00267-2 
Dueñas C., Fernández M.C. \& Cañete S., $2005-{ }^{222} R n$ concentrations and the radiation exposure levels in the Nerja Cave. Radiation Measurements, 40: 630-632. http://dx.doi.org/10.1016/j.radmeas.2005.02.019

Dueñas C., Fernández M.C., Cañete S., Pérez M. \& Gordo E., 2011 - Seasonal variations of radon and the radiation exposure levels in Nerja cave, Spain. Radiation Measurements, 46: 1181-1186. http://dx.doi.org/10.1016/j.radmeas.2011.06.039

Faimon J., Štelcl J. \& Sas D., 2006 - Anthropogenic $\mathrm{CO}_{2}-$ flux into cave atmosphere and its environmental impact: A case study in the Císařská Cave (Moravian Karst, Czech Republic). Science of the Total Environment, 369: 231245.http://dx.doi.org/10.1016/j.scitotenv.2006.04.006

Faimon J., Troppová D., Baldík V. \& Novotný R., 2012 Air circulation and its impact on microclimatic variables in the Císařská Cave (Moravian Karst, Czech Republic). International Journal of Climatology, 32: 599-623. http://dx.doi.org/10.1002/joc.2298

Fairchild I.J., Smith C.L., Baker A., Fuller L., Spötl C., Mattey D., McDermott F. \& E.I.M.F., 2006 Modification and preservation of environmental signals in speleothems. Earth-Science Reviews, 75: 105-153. http://dx.doi.org/10.1016/j.earscirev.2005.08.003

Faust B. 1947 - An unusual phenomenon. National Speleological Society Bulletin, 9: 52-54.

Fernández-Cortés A., Sanchez-Moral S., Cuezva S., Cañaveras J.C. \& Abella R. 2009 - Annual and transient signatures of gas exchange and transport in the Castañar de Ibor cave (Spain). International Journal of Speleology, 38 (2): 153-162. http:/ / dx.doi.org/10.5038/1827-806X.38.2.6

Geiger R., 1966 - The climate near the ground. Harvard University Press, Cambridge, 628 p.

Gregorič A., Zidanšek A. \& Vaupotič J., 2011 Dependence of radon levels in Postojna Cave on outside air temperature. Natural Hazards and Earth System Science, 11: 1523-1528. http://dx.doi.org/10.5194/nhess-11-1523-2011

Jernigan J.W. \& Swift R.J., 2001 - A mathematical model of air temperature in Mammoth Cave, Kentucky. Journal of Cave and Karst Studies, 63: 3-8.

Kowalczk A.J. \& Froelich P.N., 2010 - Cave air ventilation and $\mathrm{CO}_{2}$ outgassing by radon-222 modeling: How fast do caves breathe? Earth and Planetary Science Letters, 289: 209-219. http://dx.doi.org/10.1016/j.eps1.2009.11.010

KowalskiA.S.\&Sánchez-CañeteE.P.,2010-Anewdefinition of the virtual temperature, valid for the atmosphere and the $\mathrm{CO}_{2}$-rich air of the vadose zone. Journal of Applied Meteorology and Climatology, 49: 1692-1695. http://dx.doi.org/10.1175/2010JAMC2534.1

Luetscher M. \& Jeannin P.-Y., 2004 - The role of winter air circulations for the presence of subsurface ice accumulations: an example from Monlési ice cave (Switzerland). Theoretical and Applied Karstology, 17: 19-25.
Luetscher M., Lismonde B. \& Jeannin P.-Y., 2008 Heat exchanges in the heterothermic zone of a karst system: Monlesi cave, Swiss Jura Mountains. Journal of Geophysical Research, 113: F02025. http://dx.doi.org/10.1029/2007JF000892

McDermott F., 2004 - Palaeo-climate reconstruction from stable isotope variations in speleothems: a review. Quaternary Science Reviews, 23: 901-918. http://dx.doi.org/10.1016/j.quascirev.2003.06.021

Perrier F. \& Richon P., 2010 - Spatiotemporal variation of radon and carbon dioxide concentrations in an underground quarry: coupled processes of natural ventilation, barometric pumping and internal mixing. Journal of Environmental Radioactivity, 101: 279-296. http://dx.doi.org/10.1016/j.jenvrad.2009.12.003

Pflitsch A. \& Piasecki J., 2003 - Detection of an airflow system in Niedzwiedzia (Bear) Cave, Kletno, Poland. Journal of Cave and Karst Studies, 65: 160-173.

Plummer W.T., 1969 - Infrasonic resonances in natural underground cavities. The Journal of the Acoustical Society of America, 46: 1074-1080. http://dx.doi.org/10.1121/1.1911823

Russell M.J. \& MacLean V.L., 2008 - Management issues in a Tasmanian tourist cave: Potential microclimatic impacts of cave modifications. Journal of Environmental Management, 87: 474-483. http://dx.doi.org/10.1016/j.jenvman.2007.01.012

Sánchez-Cañete E.P., Serrano-Ortiz P., Domingo F. \& Kowalski A.S., 2013 - Cave ventilation is influenced by variations in the $\mathrm{CO}_{2}$ - dependent virtual temperature. International Journal of Speleology, 42 (1): 1-8. http:// dx.doi.org/10.5038/1827-806X.42.1.1

Spötl C., Fairchild I.J. \& Tooth A.F., 2005 - Cave air control on dripwater geochemistry, Obir Caves (Austria): Implications for speleothem deposition in dynamically ventilated caves. Geochimica et Cosmochimica Acta, 69 (10): 2451-2468. http://dx.doi.org/10.1016/j.gca.2004.12.009

Tanahara A., Taira H. \& Takemura M., 1997 - Radon distribution and the ventilation of a limestone cave on Okinawa. Geochemical Journal, 31 (1): 49-56. http://dx.doi.org/10.2343/geochemj.31.49

White W.B., 1988 - Geomorphology and hydrology of karst terrains. Oxford univ. press, NewYork, Oxford, 480 p.

Wigley T.M.L., 1967 - Non-steady flow through a porous medium and cave breathing. Journal of Geophysical Research, 72: 3199-3205. http://dx.doi.org/10.1029/JZ072i012p03199

Wigley T.M.L. \& Brown M.C., 1971 - Geophysical applications of heat and mass transfer in turbulent pipe flow. Boundary-Layer Meteorology, 1: 300-320. http://dx.doi.org/10.1007/BF02186034

Wigley T.M.L. \& Brown M.C., 1976 - The physics of caves. In: Ford T.D. \& Cullingford C.H.D. (Eds.), The Science of Speleology. New York: Academic Press: 329-358. 